\title{
Characterization of the Recombinant Glutamate Decarboxylase of Lactobacillus brevis G144 Isolated from Galchi Jeotgal, a Korean Salted and Fermented Seafood
}

\author{
Jeong A Kim ${ }^{1}$, Ji Yeong Park ${ }^{2}$, and Jeong Hwan Kim ${ }^{1,2 *}$ \\ ${ }^{1}$ Institute of Agriculture and Life Science, ${ }^{2}$ Division of Applied Life Science BK21 4, Graduate School, Gyeongsang National University, \\ Jinju 52828, Republic of Korea
}

Received: February 27, 2020 / Revised: April 11, 2020 / Accepted: April 13, 2020

\begin{abstract}
A $\gamma$-aminobutyric acid (GABA)-producing microorganism was isolated from galchi (hairtail fish, Trichiurus lepturus) jeotgal, a Korean salted and fermented seafood. The G144 isolate produced GABA excessively when incubated in MRS broth containing monosodium glutamate (MSG, 3\%, w/v). G144 was identified as Lactobacillus brevis through $16 \mathrm{~S}$ rRNA and recA gene sequencing. gadB and gadC encoding glutamate decarboxylase (GAD) and glutamate/GABA antiporter, respectively, were cloned and gadB was located downstream of gadC. The operon structure of gadCB was confirmed by reverse transcription (RT)-polymerase chain reaction. gadB was overexpressed in Escherichia coli and recombinant GAD was purified and its size was $54.4 \mathrm{kDa}$ as evidenced by SDS-PAGE results. Maximum GAD activity was observed at pH 5.0 and $40{ }^{\circ} \mathrm{C}$ and the activity was dependent on pyridoxal 5 '-phophate. The $K_{m}$ and $V_{\max }$ of GAD were $8.6 \mathrm{mM}$ and $0.01 \mathrm{mM} / \mathrm{min}$, respectively.
\end{abstract}

Keywords: GABA, Lactobacillus brevis, glutamate decarboxylase, galchi jeotgal

\section{Introduction}

$\gamma$-Aminobutyric acid (GABA) is a non-protein amino acid that is widely distributed among microorganisms, animals, and plants [1, 2]. It is a major neurotransmitter inhibitor in animals and has various physiological functions including hypotensive, anti-anxiety, tranquilizing, analgesic, and diuretic effects [1]. GABA was also shown to improve visual function of old animals [3]. GABA is produced from L-glutamate by the action of glutamate decarboxylase (GAD, E.C. 4.1.1.15), a pyridoxal 5'phophate (PLP)-dependent enzyme encoded by gadB gene [2]. Although many different microorganisms pro-

\section{*Corresponding author}

Tel: +82-55-772-1904, Fax: +82-55-772-1909

E-mail: jeonghkm@gnu.ac.kr duce GABA, lactic acid bacteria (LAB) are the most wellknown, and currently used for the production of various GABA-containing fermented foods [4-7]. LAB produce organic acids such as lactic acid and acetic acid as major metabolites during growth on various sugars, lowering $\mathrm{pH}$ of surrounding environments. Conversion of glutamate into GABA is one of the responses which prevent rapid decrease in cellular $\mathrm{pH}$ [8]. Previously, we isolated LAB producing GABA from Korean fermented foods including Lactobacillus zymae GU240 from kimchi [9], Lb. sakei A156 and Enterococcus avium M5 from myeolchi (anchovy) jeotgals [10, 11]. In this study, a new GABA producing Lactobacillus brevis G144 was isolated from galchi (hairtail fish) jeotgal, a Korean traditional salted and fermented sea food. Lb. brevis G144 possesses high GABA producing capacity, even higher than $L b$. 
zymae GU240 and Lb. sakei A156 which have been used as positive controls for screening isolates. Thus $L b$. brevis G144 seems promising as a starter for the production of fermented foods with high GABA contents. The gadB gene of Lb.brevis G144 was cloned and overexpressed in Escherichia coli BL21(DE3). Recombinant GAD was purified and the properties of GAD were examined.

\section{Materials and Methods}

\section{Isolation of GABA Producing LAB from Galchi Jeotgal}

Galchi (hairtail fish, Trichiurus lepturus) jeotgal was purchased at a local market in Jinju (Gyeongnam, South Korea) in the spring of 2019. Jeotgal was homogenized with $0.1 \%$ peptone water by using a stomacher ${ }^{\circledR} 80$ (Seward, USA), and serially diluted. Diluted samples were spreaded on lactobacilli MRS (Acumedia, USA) agar plates with $1 \% \mathrm{CaCO}_{3}$ and $0.006 \%$ bromocresol purple. Yellow colonies with clear zones were selected as putative LAB after $48 \mathrm{~h}$ incubation at $30^{\circ} \mathrm{C}$. LAB producing GABA were screened by thin layer chromatography (TLC). Three isolates were co-inoculated into $1 \mathrm{ml}$ of MRS broth with 3\% (w/v) MSG (Sigma-Aldrich, USA), and the inoculated cultures were incubated for $48 \mathrm{~h}$ at $30^{\circ} \mathrm{C}$. Cultures were centrifuged at $12,000 \times g, 4{ }^{\circ} \mathrm{C}$ for $5 \mathrm{~min}$, and $1 \mu \mathrm{l}$ of supernatant was spotted on an activated silica gel plate (Silica gel 60 F254; Merck Co., Germany). After separated in $n$-butanol: acetic acid: water $(4: 1: 1, \mathrm{v} / \mathrm{v} / \mathrm{v})$, the plate was treated with $2 \%$ ninhydrin solution and developed at $70^{\circ} \mathrm{C}$ for $10 \mathrm{~min}$. For samples showing strong GABA production, each isolate was individually inoculated into $1 \mathrm{ml}$ of MRS broth and GABA production was tested again.

\section{Identification of GABA-Producing LAB}

GABA-producing isolates were identified by $16 \mathrm{~S}$ rRNA gene and $r e c A$ gene sequencing. 16S rRNA genes were amplified using primer 27F (5'-AGAGTTTGATCMTGGCTCAG-3') and 1492R (5'-TACGGYTACCTTGTTACGACTT-3'). recA gene was amplified using brevisF (5'ATGGCTGACGAACGACAAGCGG-3') and brevisR (5'GGCTGATTTGTCTGGTGCTAACTC-3'). Amplification was done in a volume of $50 \mu \mathrm{l}$ consisting of $5 \mu \mathrm{l}$ of DNA (100 ng), $0.5 \mu \mathrm{l}(1 \mathrm{U})$ of EX Taq DNA polymerase (Takara, Japan), $5 \mu \mathrm{l}$ of $10 \times \mathrm{EX}$ Taq buffer, $5 \mu \mathrm{l}$ dNTP mixture (2.5 mM each), 10 pmol of each primer, and $33.5 \mu \mathrm{l}$ of distilled water. The amplification conditions for $16 \mathrm{~S}$ rRNA genes were as follows; $94^{\circ} \mathrm{C}$ for $5 \mathrm{~min}$ followed by 30 cycles of $94^{\circ} \mathrm{C}$ for $30 \mathrm{~s}, 58^{\circ} \mathrm{C}$ for $45 \mathrm{~s}, 72^{\circ} \mathrm{C}$ for $1 \mathrm{~min}$, and a final extension at $72^{\circ} \mathrm{C}$ for $4 \mathrm{~min}$. Conditions for recA gene amplification were as follows; $94^{\circ} \mathrm{C}$ for 5 min followed by 30 cycles of $94^{\circ} \mathrm{C}$ for $30 \mathrm{~s}, 61^{\circ} \mathrm{C}$ for $45 \mathrm{~s}$, $72^{\circ} \mathrm{C}$ for $1 \mathrm{~min}$, and a final extension at $72^{\circ} \mathrm{C}$ for $4 \mathrm{~min}$. Amplified fragments were ligated with pGEM-T easy vector (Promega, USA) and sequenced. Nucleotide sequences were analyzed using BLAST (http://blast.ncbi. nlm.nih.gov/Blast.cgi) at NCBI (National Center for Biotechnology Information).

\section{Measurement of GABA using GC/MS}

Isolates were grown in MRS broth with $3 \%(\mathrm{w} / \mathrm{v}) \mathrm{MSG}$ for $48 \mathrm{~h}$ at $30^{\circ} \mathrm{C}$. Culture supernatant was obtained by centrifugation at $12,000 \times \mathrm{g}$ for $10 \mathrm{~min}$. Two $\mu \mathrm{l}$ of supernatant was completely dried by vacuum CentriVao concentrator (Labconco, USA) at $40^{\circ} \mathrm{C}$. For derivatization, the dried extract was methoximated with $70 \mu \mathrm{l}$ of methoxyamine hydrochloride in pyridine $(20 \mathrm{mg} / \mathrm{ml})$ at $37^{\circ} \mathrm{C}$ for $90 \mathrm{~min}$ and silylated by $70 \mu \mathrm{l}$ of $N, O$-bis (trimethylsilyl) trifluoroacetamide (BSTFA) at $70^{\circ} \mathrm{C}$ for $30 \mathrm{~min}$. The derivatized sample was analyzed by GC/MS using a Shimazu GC-2010 plus (Shimazu, Japan) equipped with DB-5 MS column $(30 \mathrm{~m} \times 0.25 \mathrm{~mm}$ id, $0.25 \mu \mathrm{m}$ film thickness, $\mathrm{J} \& \mathrm{~W}$ Scientific, USA). The injection temperature was set at $200^{\circ} \mathrm{C}$ and the oven temperature was maintained at $70^{\circ} \mathrm{C}$ for $2 \mathrm{~min}$, increased to $320^{\circ} \mathrm{C}$ at $10^{\circ} \mathrm{C} / \mathrm{min}$, and then held at $320^{\circ} \mathrm{C}$ for $5 \mathrm{~min}$. The GC column effluent was analyzed by a Shimadzu GC/MS-TQ 8030 (Japan) with the electron impact (EI) ionization mode. The ion source temperature was $230^{\circ} \mathrm{C}$. The interface temperature was $280^{\circ} \mathrm{C}$ and ions were generated by a $70 \mathrm{eV}$. Effluents were monitored in the full scan mode in the range of $45-500 \mathrm{~m} / \mathrm{z}$ with $0.3 \mathrm{sec}$ of scan event time and $2000 \mathrm{u} / \mathrm{sec}$ of scan speed. Detector voltage was $0.1 \mathrm{kV}$ and threshold was 100 .

\section{Growth Characteristics of $\mathbf{L b}$. brevis G144}

Lb. brevis G144 was grown in MRS broth for $24 \mathrm{~h}$ at $30^{\circ} \mathrm{C}$ and the culture was used to inoculate $50 \mathrm{ml}$ of MRS broth $(1 \%, v / v)$. Inoculated culture was incubated under different conditions for $120 \mathrm{~h}$ at $30^{\circ} \mathrm{C}$ : different temperature $\left(4,10,25,30,37\right.$, and $\left.45^{\circ} \mathrm{C}\right)$, different initial $\mathrm{pH}(\mathrm{pH}$ 
3-10), and different $\mathrm{NaCl}$ concentration (1, 3, 5, 8, and $10 \%, \mathrm{w} / \mathrm{v})$. Growth was monitored by measuring $\mathrm{OD}_{600}$ value at time intervals.

\section{Cloning of gadB and gadC genes}

gadB was amplified from genome of $L b$. brevis G144 by using the primer set used for cloning of $\operatorname{gad} B$ from $L b$. zymae GU240: gadBF (5'-CCCCTGCAGTTAAGGAGGCAAGCCATAT-3') and gadBR (5'-GGGAAGCTTTAACTCACCATTACTCGC-3') [9]. gadC was amplified by using a primer set based on gadC from $L b$. brevis ATCC 367: gadCF (5'-GTTGTGAAGGGATTGTGTAG-3') and gadCR (5'-CACCAAAGGCAGCATCAA-3') [9]. Amplified fragments were ligated with pGEM T-Easy vector (Promega). E. coli DH5 $\alpha$ cells were transformed with the ligation mixture by a standard protocol. DNA sequence analysis was done by using BLAST.

\section{Reverse Transcription (RT)-PCR}

RNA was isolated from $L b$. brevis G144 by the Trizolbead method [10]. RT-PCR was done after DNase (RQ1, RNase free DNase, Promega) treatment. One step RTPCR kit (Intron, Korea) was used and the reaction mixture consisted of $8 \mu \mathrm{l}$ of RT-PCR premixture, $1 \mu \mathrm{l}$ of forward primer, $1 \mu \mathrm{l}$ of reverse primer, $1 \mu \mathrm{l}$ of RNase inhibitor, and $9 \mu \mathrm{l}$ of RNase free water. Primers used for gadC are A (5'-ATTGTTTACGCCTATGGGGCCT-3') and B (5'-GAT CCACATTGACACCTAGCTGCA-3'). Primers used for gadB are C (5'-GGGCAATCCT TACCCACCAATACA-3') and D (5'-ACCAAAGGCAGCA TCAACGTGA-3'). The reaction was started by $30 \mathrm{~min}$ incubation at $45^{\circ} \mathrm{C}$, followed by initial PCR activation for $5 \mathrm{~min}$ at $94^{\circ} \mathrm{C}$. PCR cycles consisted of denaturation at $95^{\circ} \mathrm{C}$ for $30 \mathrm{~s}$, annealing at $60^{\circ} \mathrm{C}$ for $30 \mathrm{~s}$, and extension at $72^{\circ} \mathrm{C}$ for $1 \mathrm{~min}$. A total of 29 cycles were repeated, and the final extension was done at $72^{\circ} \mathrm{C}$ for $5 \mathrm{~min}$.

\section{Overexpression of $\mathrm{gadB}$ in $\mathrm{E}$. coli and Purification of GAD}

$\operatorname{gadB}$ was amplified from chromosome of $L b$. brevis G144 by using a primer pair: F (5'-GGGCATATGAATAAAAACGATCAGG-3', NdeI site underlined) and R (5'GGGCTCGAGACTTCGAACGGTGGT-3', XhoI site underlined). Amplification conditions were as follows: $94^{\circ} \mathrm{C}$ for $5 \mathrm{~min} ; 30$ cycles of $94^{\circ} \mathrm{C}$ for $30 \mathrm{~s}, 60^{\circ} \mathrm{C}$ for $30 \mathrm{~s}$, $72^{\circ} \mathrm{C}$ for $2 \mathrm{~min}$; and the final extension at $72^{\circ} \mathrm{C}$ for $10 \mathrm{~min}$. The amplified fragment was ligated into
pET26b(+) (Novagen, $5.36 \mathrm{~kb}, \mathrm{Kan}^{\mathrm{R}}$ ) and the ligation mixture was introduced into $E$. coli BL21(DE3). E. coli cells harboring pETG144 (pET26b(+) with gadB at NdeI and $X h o I$ sites) were grown in LB broth $(100 \mathrm{ml})$ containing kanamycin $(60 \mu \mathrm{g} / \mathrm{ml})$ at $37^{\circ} \mathrm{C}$ until the $\mathrm{OD}_{600}$ value reached 0.6 . Then isopropyl $\beta$-D-1-thiogalactopyranoside (IPTG) was added to $1 \mathrm{mM}$ and growth continued for $14 \mathrm{~h}$ at $20^{\circ} \mathrm{C}$. Cells were harvested by centrifugation at $12,000 \times \mathrm{g}$ for $15 \mathrm{~min}$ at $4^{\circ} \mathrm{C}$, washed three times with phosphate buffered saline (PBS, $\mathrm{pH} 7.4$ ), and resuspended in lysis buffer $\left(50 \mathrm{mM} \mathrm{NaH}_{2} \mathrm{PO}_{4}, 300 \mathrm{mM} \mathrm{NaCl}\right.$, and $10 \mathrm{mM}$ imidazole, $\mathrm{pH}$ 7.0). Cells were disrupted by using an ultrasonicator (Bandelin Electronic, Germany). The disrupted cells were centrifuged at $12,000 \times g$ for $15 \mathrm{~min}$, and the pellet (insoluble fraction) and supernatant (soluble fraction) were obtained. The soluble fraction was loaded onto a Ni-NTA column (GE Healthcare, Sweden). Bound recombinant GAD was eluted by buffer containing imidazole (40-500 mM). Protein concentration was determined by Bradford method using a BioRad protein assay kit [12]. SDS-PAGE was done using a $12 \%(\mathrm{w} / \mathrm{v})$ acrylamide gel.

\section{Enzyme Assay and Properties of Recombinant GAD}

The activity of recombinant GAD was measured by a GABase method [13]. The enzyme solution ( $1 \mu \mathrm{g}$ GAD in $0.1 \mathrm{ml}$ of lysis buffer) and $0.1 \mathrm{ml}$ of $4 \mathrm{M}$ ammonium sulfate were mixed. After $30 \mathrm{~min}$ of pre-incubation, the enzyme solution was mixed with $1.3 \mathrm{ml}$ of substrate (20 mM MSG, $0.2 \mathrm{mM}$ PLP, and, 0.2 M pyridine- $\mathrm{HCl}$, $\mathrm{pH} 4.5$ ), and incubated for $1 \mathrm{~h}$. The reaction was stopped by boiling for $5 \mathrm{~min}$, and the amount GABA was analyzed by GABase assay as described previously [9]. One unit of GAD activity was defined as the amount of enzyme producing $1 \mu \mathrm{mol}$ GABA per minute under the experimental conditions.

Purified recombinant GAD $(4 \mu \mathrm{g})$ was incubated in substrate buffer (20 mM MSG, $0.2 \mathrm{mM}$ PLP) at different $\mathrm{pH}$ ( $\mathrm{pH} 3-10)$ for $1 \mathrm{~h}$ at $37^{\circ} \mathrm{C}$, and then the remaining GAD activity was measured by GABase assay. Purified GAD $(4 \mu \mathrm{g})$ was incubated at temperature ranging from $25^{\circ} \mathrm{C}$ to $65^{\circ} \mathrm{C}$ for $30 \mathrm{~min}(\mathrm{pH} \mathrm{5.0)}$ and the remaining GAD activity was measured by GABase assay. The effect of PLP concentration ( 0 to $1.8 \mathrm{mM}$ ) and chemicals ( $2 \mathrm{mM}$ ) on the GAD activity were also determined by incubating GAD (4 $\mu \mathrm{g})$ for $1 \mathrm{~h}(\mathrm{PLP})$ and $30 \mathrm{~min}$ (chemicals) at $40^{\circ} \mathrm{C}$ 
and $\mathrm{pH}$ 5.0. For testing stability, $10 \mu \mathrm{g}$ of recombinant GAD was incubated at $40^{\circ} \mathrm{C}$ and $\mathrm{pH} 5.0$, and the remaining GAD activity was measured at 1,3 and $6 \mathrm{~h}$.

\section{Kinetic measurements of Recombinant GAD}

The effect of MSG concentration on the GAD activity was determined in total $1.5 \mathrm{ml}$ mixture. Purified GAD (25.49 $\mu \mathrm{l}, 10 \mu \mathrm{g})$ was mixed with $74.51 \mu \mathrm{l}$ of enzyme solution (10 mM imidazole, $300 \mathrm{mM} \mathrm{NaCl}, 50 \mathrm{mM}$ Sodium phosphate buffer, $\mathrm{pH} 5.0$ ) and $100 \mu \mathrm{l}$ of $4 \mathrm{M}$ ammonium sulfate. After 30 min of pre-incubation, the enzyme solution was mixed with $1.3 \mathrm{ml}$ of substrate $(0-100 \mathrm{mM}$ MSG, 0.2 M pyridine-HCl, $0.2 \mathrm{mM}$ PLP, pH 5.0), and incubated for $1 \mathrm{~h}$. The reaction was stopped by boiling for $5 \mathrm{~min}$, and the amount of GABA was analyzed by GABase assay. The Michaelis constant $(\mathrm{Km})$ and maximum velocity (Vmax) were calculated using a Lineweaver-Burk plot.

\section{Results and Discussion}

\section{Isolation and Identification of GABA-Producing LAB from Galchi Jeotgal}

A total of 1,000 putative LAB were isolated from galchi jeotgal and screened for GABA production by TLC. Among the several positive isolates, G144 was the best producer as determined by TLC (Fig. 1). G144 was a non-spore forming, Gram-positive, facultative anaerobic, and short-rod shaped organism without flagella. API kit test results indicated that G144 was Lactobacillus brevis (results not shown). For more accurate identification, 16S rRNA and $\operatorname{rec} A$ genes were amplified and

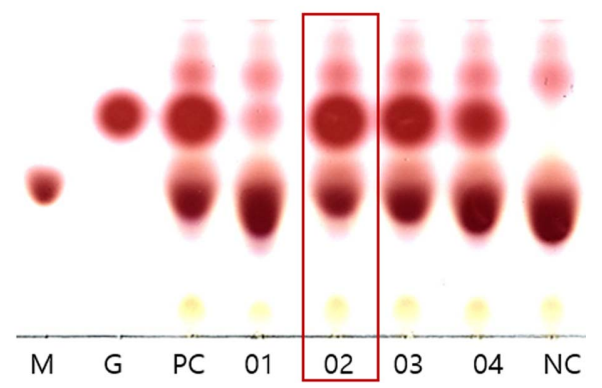

Fig. 1. Thin-layer chromatogram showing GABA production by $\boldsymbol{L}$ b. brevis G144. M, $0.8 \mu \mathrm{l}$ of $100 \mathrm{mM} \mathrm{MSG;} \mathrm{G,} 0.8 \mu \mathrm{l}$ of 100 mM GABA; PC, Lb. zymae GU240 (positive control); 01, S41; 02, G144; 03, G145; 04, G167; NC, Leuconostoc mesenteroides ATCC10830 (negative control). sequenced. BLAST search for the 16S rRNA gene (1,387 nucleotides, MN065577) showed that the sequence showed $100 \%$ identity with those of $L b$. brevis MG4563, $L b$. brevis KT38-3, Lb. brevis SDCM, and $L b$. brevis LMT1-73 (data not shown). BLAST search for the recA gene (1,013 nucleotides, MN065580) also indicated that the sequence was $100 \%$ identical with those of $L b$. brevis UCCLBBS124 and LMT1-73 (data not shown). From these results, G144 was identified as Lb. brevis, and named $L b$. brevis G144.

GABA content of culture supernatant of $L b$. brevis G144 was $14.58 \pm 1.74 \mathrm{mM}$ as determined by GC/MS (results not shown). Meanwhile, the GABA content of Lb. zymae GU240 was $12.16 \pm 1.05 \mathrm{mM}$ under the same conditions. Lb. zymae GU240, previously isolated from kimchi and a profuse GABA producer, has been used as a positive control [9]. Both cultures were grown under the same conditions and samples prepared by the same way. The result indicated that G144 is better than $L$. zymae GU240 in terms of GABA production.

\section{Growth Characteristics of $\boldsymbol{L} b$. brevis G144}

Lb. brevis G144 grew rapidly at 25,30 and $37^{\circ} \mathrm{C}$ in MRS broth, reaching $\mathrm{OD}_{600}$ value of $1.32,1.47$ and 1.52 , respectively in $24 \mathrm{~h}$, and $1.49,1.56$ and 1.49 , respectively in $96 \mathrm{~h}$ (Fig. 2A). Lb. brevis G144 grew at $45^{\circ} \mathrm{C}$, and reached $\mathrm{OD}_{600}$ value of 1.17 and 1.34 in $24 \mathrm{~h}$ and $48 \mathrm{~h}$, respectively. But it did not grow at $4^{\circ} \mathrm{C}$ and $-1^{\circ} \mathrm{C}$ in $120 \mathrm{~h}$. At $15^{\circ} \mathrm{C}$, growth was delayed until $24 \mathrm{~h}$ and then grew rapidly, reaching $\mathrm{OD}_{600}$ value of 1.45 in 120 h. Lb. brevis G144 grew rapidly at $3 \%(\mathrm{w} / \mathrm{v}) \mathrm{NaCl}$ and reached $\mathrm{OD}_{600}$ value of 1.56 at $48 \mathrm{~h}$, the same degree of growth of control $(0 \% \mathrm{NaCl})$ (Fig. 2B). At $5 \% \mathrm{NaCl}$, growth was delayed until $24 \mathrm{~h}$ and then growth regained, reaching $\mathrm{OD}_{600}$ value of 1.44 at 120 h. Lb. brevis G144 grew very slowly at $8 \% \mathrm{NaCl}$, and did not grow at $10 \% \mathrm{NaCl}$ in 120 h. Lb. brevis G144 possesses weak salt tolerance, and thus could be used as a starter for low-salt jeotgals or other fermented foods where the $\mathrm{NaCl}$ concentration does not exceed $8 \%$.

Lb. brevis G144 grew well at the initial $\mathrm{pH}$ of 4.0 to 8.0, reaching $\mathrm{OD}_{600}$ values of $1.41-1.60$ at $24 \mathrm{~h}$ (Fig. $2 \mathrm{C}$ ). Lb. brevis G144 grew slowly at the initial $\mathrm{pH}$ of 3 and 9, reaching $\mathrm{OD}_{600}$ values of 1.2 at $120 \mathrm{~h}$. But $L b$. brevis G144 grew very slowly at the initial $\mathrm{pH}$ of 10 , reaching 0.69 at $120 \mathrm{~h}$. 

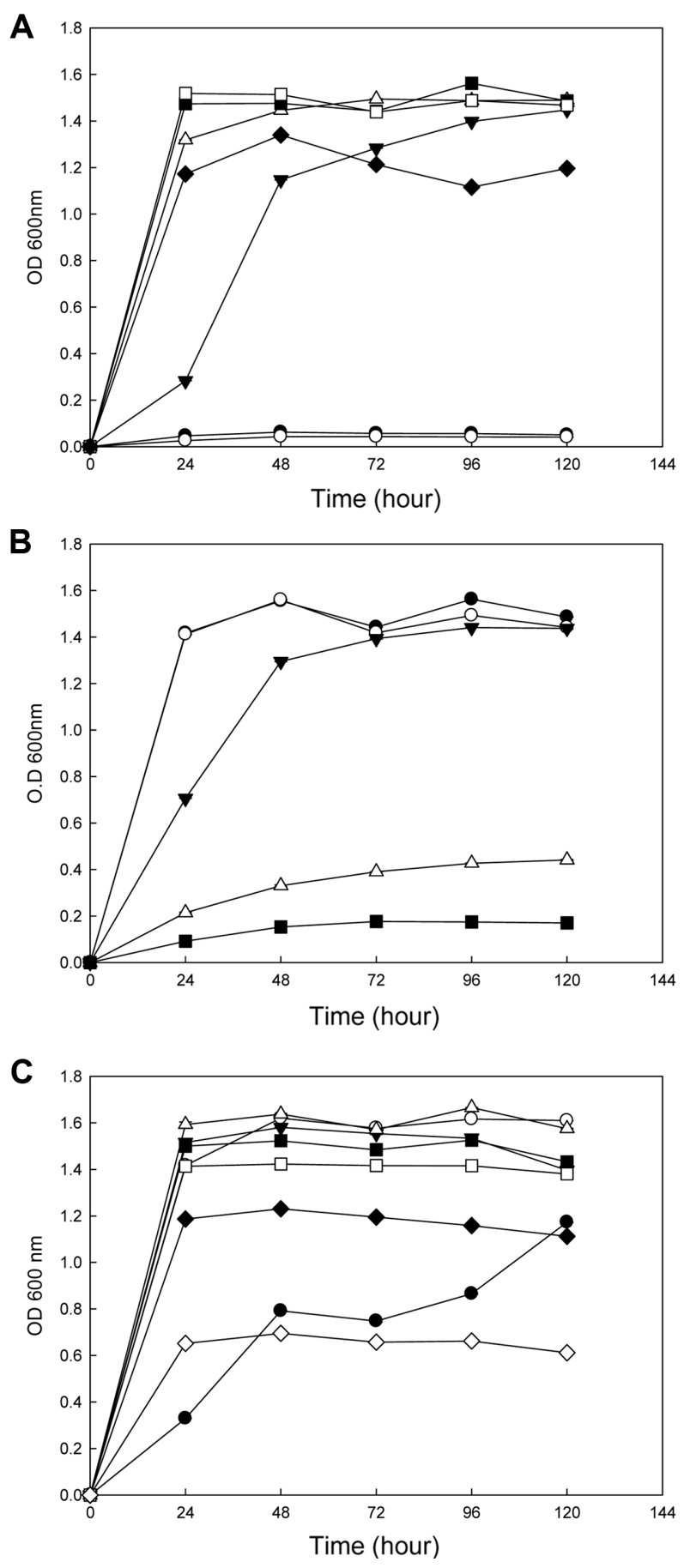

Fig. 2. Growth of $L b$. brevis G144 in MRS broth under different conditions. The absorbance of each culture was measured at $600 \mathrm{~nm}$ and each value represents the mean value from three independent measurements. (A) Temperature: $\bullet,-1{ }^{\circ} \mathrm{C}$; $\mathrm{O}, 10^{\circ} \mathrm{C}$; $\nabla, 15^{\circ} \mathrm{C} ; \triangle, 25^{\circ} \mathrm{C} ; \mathbf{\square}, 30^{\circ} \mathrm{C} ; \square, 37 ; \bullet, 45^{\circ} \mathrm{C}$. (B) NaCl concentration: $\bullet, 0 \%$;, $3 \% ; \nabla, 5 \% ; \triangle, 8 \%$; $\mathbf{\square}, 10 \%$. (C) initial pH of MRS broth: $\bullet, \mathrm{pH} 3 ; \circ, \mathrm{pH} 4 ; \nabla, \mathrm{pH} 5 ; \triangle, \mathrm{pH} 6 ; \mathbf{a}, \mathrm{pH} 7 ; \square, \mathrm{pH} 8 ; \diamond, \mathrm{pH} 9 ; \diamond$, $\mathrm{pH} 10$.

\section{Cloning of gadB and gadC}

A $1.5 \mathrm{~kb}$ fragment containing gadB was amplified and the nucleotide sequence was determined (accession number MN102361). An ORF consisting of 1,440 nucleotides was located, and the amino acids translated from the nucleotide sequence showed high homologies to GADs in the database. gadB could encode a protein of 479 amino acids with the calculated size of $53.50 \mathrm{kDa}$ and isoelectric point (pI) of 4.95. The GAD from $L b$. brevis G144 contained a highly conserved catalytic domain (T224, D255, H287, K288 in Fig. 4A) that belongs to the PLP-dependent decarboxylase superfamily [13]. The amino acid sequence of GAD from $L b$. brevis G144 was aligned with those of GADs from other LAB. Lb. brevis G144 showed 99\% identity with the GAD from Lb. zymae GU240 (AHF72525), Lb. brevis ATCC367 (ABJ63253), and Lb. brevis BH2 (AIC75925), differing only at two amino acids. The GAD from Lb. brevis G144 differed from those from Lb. sakei A156 (KM982734),
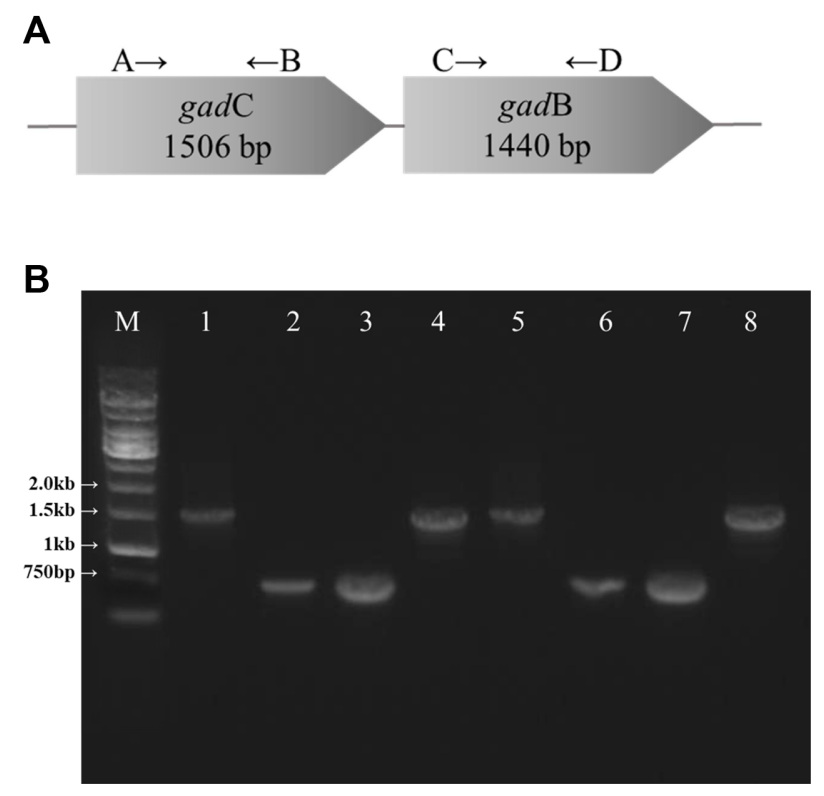

Fig. 3. Reverse transcription (RT)-PCR results showing the operon structure of $\operatorname{gadCB}$. (A) Operon structure of $\operatorname{gadCB}$ genes in $L b$. brevis G144. The arrows indicate the binding sites for primers used for RT-PCR. (B) Agarose gel electrophoresis for RT-PCR products. Lane M, GeneRuler $1 \mathrm{~kb}$ DNA ladder (Thermo scientific, USA); 1-4, RNA preps; 5-8, RNA preps treated with DNase I. Lanes 1 and 5, RT-PCR using universal primers (27F and 1492R) for $16 \mathrm{~S}$ rRNA genes; 2 and 6, RT-PCR using primers $C$ and D for gadB; 3 and 7, RT-PCR using primers A and B for gadC; 4 and 8, RT-PCR using primers $A$ and $D$ for gadCB. 


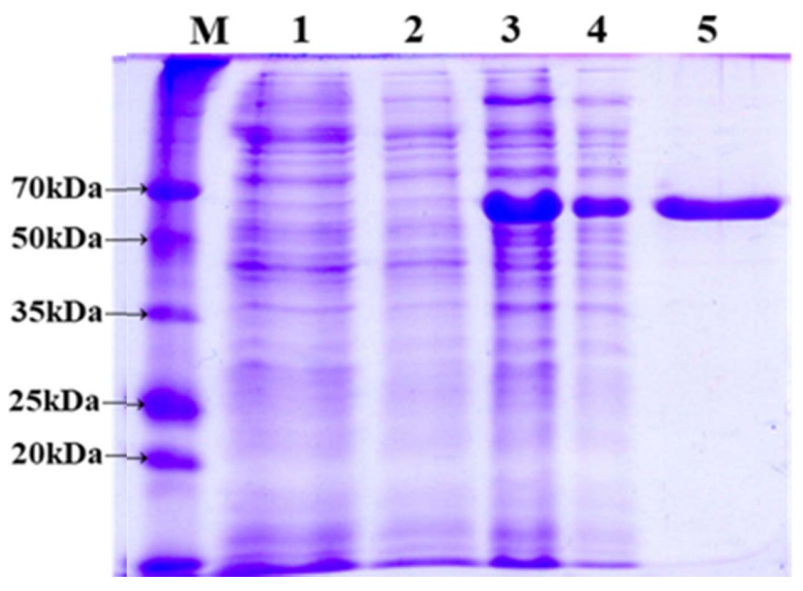

Fig. 4. SDS-PAGE of recombinant GAD. $M$, size marker (Dokdo-mark, Eplis Biotech, Korea); 1, insoluble fraction from $E$. coli BL21 [pET26(b)+] (negative control); 2, soluble fraction from E. coli BL21 [pET26(b)+] (negative control); 3, insoluble fraction from E. coli BL21 [pETG144]; 4, soluble fraction from $E$. coli BL21 [pETG144]; 5, GAD eluted from a HiTrap affinity column at $300 \mathrm{mM}$ imidazole concentration.

Lb. brevis CGMCC1306 (AEY81112.1), and Lb. brevis IFO12005 (BAF99137.2) at three amino acids.

The nucleotide sequence of gadC was determined (MN102362). An ORF of 1,506 nucleotides was located, which could encode a protein of 501 amino acids with the calculated molecular mass of $55.15 \mathrm{kDa}$ and isoelectric point (pI) of 9. gadC from $L b$. brevis G144 showed 99.9\% identity with the gadC gene from $L b$. zymae GU240 (AHF72525), Lb. brevis ATCC367 (ABJ63253), Lb. sakei A156 (KM982734), Lb. brevis CGMCC1306 (AEY81112.1), $L b$. brevis IFO12005 (BAF99137.2), and $L b$. brevis $\mathrm{BH} 2$ (AIC75925).

It was found that $\operatorname{gadC}$ was located in the immediate upstream of $\operatorname{gadB}$ with just 55 nucleotides apart (data not shown). This strongly indicated the operon structure of gadCB in Lb. brevis G144 (Fig. 3A). RT-PCR was done for RNA sample prepared from $L b$. brevis G144. A transcript, $1.5 \mathrm{~kb}$, covering both $\operatorname{gadC}$ and $\operatorname{gadB}$ was detected (Fig. 3B), confirming the gadCB operon structure in $L b$. brevis G144. The same operon structure was reported for Lb. brevis IFO12005 [14], Lactococcus lactis subsp. lactis 01-7 [15], and Lb. zymae GU240 [9]. However, except for $L b$. zymae, the operon structure was just suspected from the close locations of two genes, but not proven experimentally by methods such as RTPCR used in this work.

\section{Overexpression of gadB in E. coli BL21(DE3) and Purifica- tion of Recombinant GAD}

The gadB gene from $L b$. brevis G144 was overexpressed in E. coli BL21(DE3) and recombinant GAD was produced in IPTG induced cells. A control, E. coli BL21(DE3) harboring intact $\mathrm{pET} 26 \mathrm{~b}(+)$, did not produce the protein (Fig. 4, lane 1 and 2). Recombinant GAD was observed from both soluble and insoluble fractions of cell extract. The soluble fraction was loaded onto a Ni-NTA column, and bound GAD was eluted by imidazole at 300 $\mathrm{mM}$ concentration (Fig. 4). Sufficiently purified GAD was obtained, and the size was $54.4 \mathrm{kDa}$ on a SDS gel, matching well with the expected size of GAD with additional His tag (Fig. 4).

\section{Properties of Recombinant GAD}

The optimum temperature for recombinant GAD was $40^{\circ} \mathrm{C}$ (Fig. 5A, and Table 1). It was lower than that of GAD from Enterococcu avium M5 $\left(45^{\circ} \mathrm{C}\right)$ [11]. The optimum $\mathrm{pH}$ for recombinant GAD was 5.0 (Fig. 5B). Most GADs are active at $\mathrm{pH} 4.0-5.0$ as reported for GAD from Lactococcus lactis (pH 4.7) [16], Lb. brevis CGMCC1306 (pH 4.8) [17], E. coli (pH 4.4) [18] Lb. sakei A156 (pH 5.0) [10], Lb. zymae GU240 (pH 4.5) [9], and S. thermophiles Y2 (pH 4.2) [19]. GAD is believed to be involved in maintaining cellular $\mathrm{pH}$ near neutral $\mathrm{pH}$ under acidic conditions and this role is important for LAB [20]. The GAD of Lb. brevis G144 depends on PLP for its activity (Fig. 5C) and the highest activity was obtained around $0.6 \mathrm{mM}$, but the degree of increase was small at PLP concentrations above $0.02 \mathrm{mM}$. The effect of chemicals $(2 \mathrm{mM})$ on GAD activity was examined (Fig. 5D). The activity was increased by $\mathrm{CaCl}_{2}(128 \%), \mathrm{FeCl}_{3}(112 \%), \mathrm{KCl}(117 \%)$, and $\mathrm{MnCl}_{2}$ (114\%), whereas it was decreased by $\mathrm{CoCl}_{2}$ (78\%), $\mathrm{CuSO}_{4}(12 \%), \mathrm{ZnCl}_{2}$ (95\%), and $\mathrm{AgNO}_{3}(20 \%)$. For testing stability in optimum $\mathrm{pH}$ and temperature $(\mathrm{pH}$ 5.0 and $40^{\circ} \mathrm{C}$ ), purified GAD was incubated up to $6 \mathrm{~h}$, and GAD remained active at $6 \mathrm{~h}$ (data not shown).

The $\mathrm{K}_{\mathrm{m}}$ of GAD from $L b$. brevis G144 was $8.6 \pm$ $0.06 \mathrm{mM}$ and $\mathrm{V}_{\max }$ was $0.010 \pm 0.0002 \mathrm{mM} / \mathrm{min}$ when MSG was used as the substrate (Table 1). The Km value was higher than those of GADs from $L b$. zymae GU240 [9], E. avium M5 [11], Lb. brevis 877G [21], L. lactis ssp. lactis 01-7 [15], Pyrococcus horikoshii [22], E. coli [18], and St. salivalivarius ssp. thermophilus Y2 [19], but lower than those from Lb. sakei A156 [10], Lb. brevis 

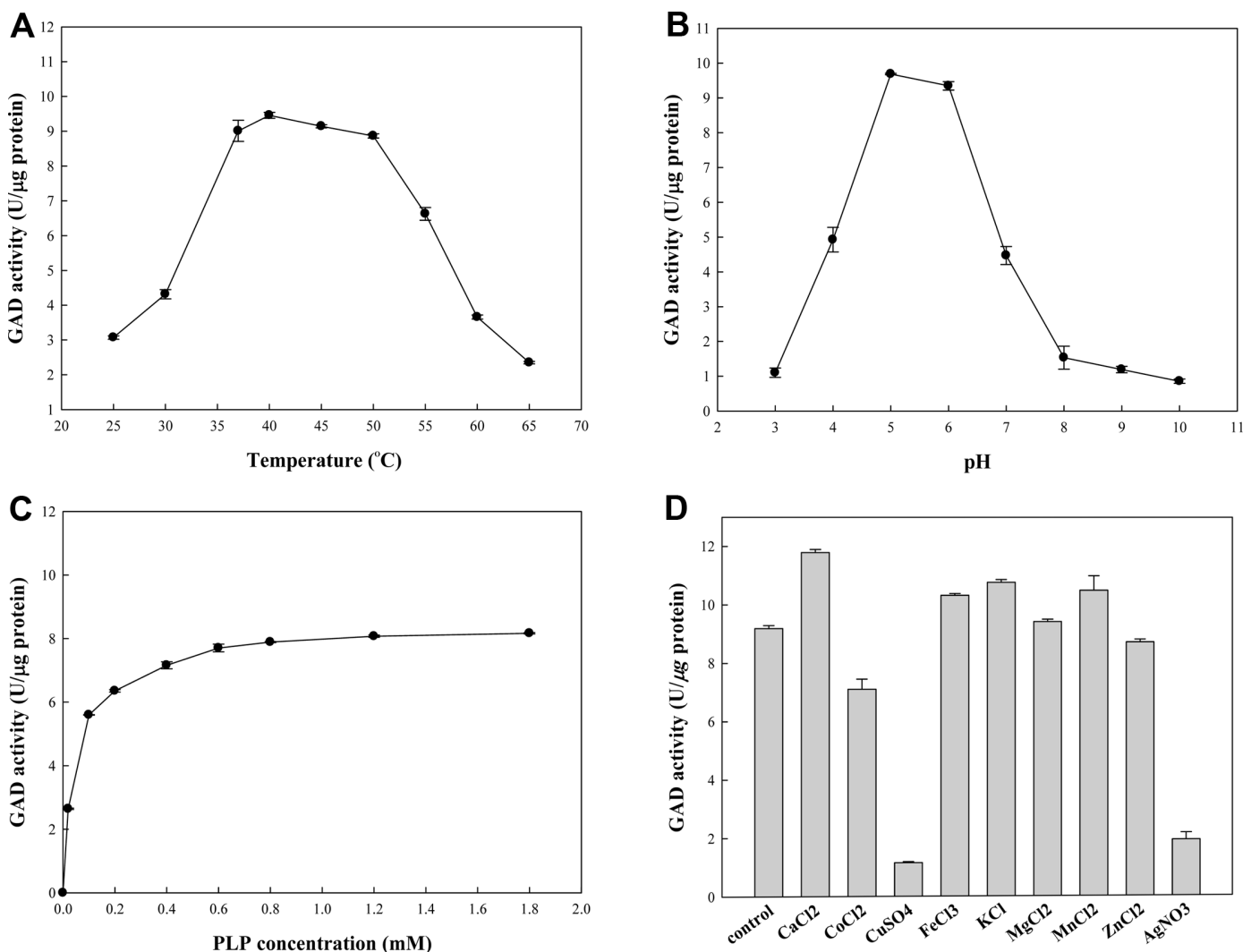

Fig. 5. Properties of recombinant GAD under different conditions. Activities of recombinant GAD were measured at different conditions. (A) temperature, $25-65^{\circ} \mathrm{C}$, (B) pH, 3-10, (C) PLP concentration, 0-1.8 mM, and (D) chemicals, $2 \mathrm{mM}$.

Table 1. Characteristics of recombinant GAD and other GADs.

\begin{tabular}{|c|c|c|c|c|}
\hline Organism & $\begin{array}{c}\text { Optimum } \\
\text { temperature }\left({ }^{\circ} \mathrm{C}\right)\end{array}$ & Optimum pH & $\mathrm{Km}(\mathrm{mM})$ & Reference \\
\hline Aspergillus oryzae & 60 & - & 13.3 & [23] \\
\hline Enterococcu avium $\mathrm{M5}^{*}$ & 55 & 4.5 & 3.26 & {$[11]$} \\
\hline Escherichia coli & - & 4.4 & 1.4 & {$[18]$} \\
\hline Lactobacillus brevis $\mathrm{G} 144^{*}$ & 40 & 5.0 & 8.6 & This study \\
\hline Lactobacillus brevis $877 \mathrm{G}^{*}$ & 45 & 5.2 & 3.6 & {$[21]$} \\
\hline Lactobacillus brevis IFO12005* & 30 & 4.2 & 9.3 & {$[14]$} \\
\hline Lactobacillus brevis CGMCC 1306* & 48 & 4.8 & 10.3 & {$[17]$} \\
\hline Lactobacillus sakei A156* & 55 & 5.0 & 16.0 & {$[10]$} \\
\hline Lactobacillus sakei OPK2-59 & 30 & 5.0 & - & {$[24]$} \\
\hline Lactobacillus paracasei NFRI 7451 & 50 & 5.0 & - & {$[25]$} \\
\hline Lactobacillus zymae GU240* & 41 & 4.5 & 1.7 & [9] \\
\hline Lactococcus lactis ssp. lactis 01-7 & - & 4.7 & 0.51 & {$[15]$} \\
\hline Streptococcus salivarius ssp. thermophilus $\mathrm{Y}^{*}$ & 55 & 4.0 & 2.3 & [19] \\
\hline Pyrococcus horikoshii* & - & 8.0 & 3.9 & {$[22]$} \\
\hline
\end{tabular}

*Recombinant GAD was used for testing properties. 
IFO12005 [14], LB. brevis CGMCC 1306 [17], and $A$. oryzae [23].

A GABA-producing $L b$. brevis G144 was isolated form galchi jeotgal and its gadB gene was cloned and overexpressed in E. coli. Lb. brevis G144 and its gadB gene might be useful for the production of GABA-enriched foods including kimchi, jeotgals, and fermented soy milk where the $\mathrm{NaCl}$ concentration does not exceed $8 \%(\mathrm{w} / \mathrm{v})$. But more studies are necessary on the growth and GABA production by $L b$. brevis G144 in such foods. Questions to be answered are how to supply precursor of GABA and PLP, a required cofactor for GAD for food fermentations. These questions must be answered before Lb. brevis G144 is used as a starter for a specific food type.

\section{Acknowledgments}

This work was supported by Korea Institute of Planning and Evaluation for Technology in Food, Agriculture, Forestry and Fisheries (IPET) through (Agricultural Microbiome R\&D Program), funded by Ministry of Agriculture, Food and Rural Affairs (MAFRA) (918005044HD070).

JA Kim and JY park were supported by BK21 Plus program, MOE, Republic of Korea.

\section{Conflict of Interest}

The authors have no financial conflicts of interest to declare.

\section{References}

1. Somkuti GA, Renve JA Jr, Steinberg DH. 2012. Molecular analysis of the glutamate decarboxylase locus in Streptococcus thermophilus ST1 10. J. Ind. Microbiol. Biotechnol. 39: 957-963.

2. Ueno H. 2000. Enzymatic and structural aspects on glutamate decarboxylase. J. Mol. Catal. 10:67-79.

3. Leventhal AG, Wang Y, Pu M, Zhou Y, Ma Y. 2003. GABA and its agonists improved visual cortical function in senescent monkeys. Science 300: 812-815.

4. Li H, Cao Y. 2010. Lactic acid bacterial cell factories for $\gamma$-aminobutyric acid. Amino Acid 39: 1107-1116.

5. Park KB, Oh SH. 2007. Production of yogurt with enhanced levels of $\gamma$-aminobutyric acid and valuable nutrients using lactic acid bacteria and germinated soybean extract. Bioresour. Technol. 98: 1675-1679.

6. Diana M, Quílez J, Rafecas M. 2014. $\gamma$-aminobutyric acid as a bioactive compound in foods: a review. J. Funct. Foods 10: 407-420.

7. Cho SY, Park MJ, Kim KM, Ryu JH, Park HJ. 2011. Production of high $\gamma$-aminobutyric acid (GABA) sour kimchi using lactic acid bacteria isolated from mukeunjee kimchi. Food Sci. Biotechnol.
20: 403-408.

8. Feehily C, Karatzas KAG. 2012. Role of glutamate metabolism in bacterial responses towards acid and other stresses. J. Appl. Microbiol. 114: 11-24.

9. Park JY, Jeong SJ, Kim JH. 2014. Characterization of a glutamate decarboxylase (GAD) gene from Lactobacillus zymae. Biotechnol. Lett. 36: 1791-1799.

10. Sa HD, Park JY, Jeong SJ, Lee KW, Kim JH. 2015. Characterization of glutamate decarboxylase (GAD) from Lactobacillus sakei A156 isolated from Jeotgal. J. Microbiol. Biotechnol. 25: 696-703.

11. Lee KW, Shim JM, Yao Z, Kim JA, Kim HJ, Kim JH. 2017. Characterization of a glutamate decarboxylase (GAD) from Enterococcus avium M5 isolated from Jeotgal, a Korean fermented seafood. J. Microbiol. Biotechnol. 27: 1216-1222.

12. Bradford MM. 1 976. A rapid and sensitive method for the quantitation of microgram quantities of protein utilizing the principle of protein-dye binding. Anal. Biochem. 72: 248-254.

13. Biase DD, Pennacchietti E. 2012. Glutamate decarboxylasedependent acid resistance in orally acquired bacteria: function, distribution and biomedical implications of the $\operatorname{gadBC}$ operon. Mol. Microbiol. 86: 770-786.

14. Hiraga K, Ueno Y, Oda K. 2008. Glutamate decarboxylase from Lactobacillus brevis: activation by ammonium sulfate. Biosci. Biotechnol. Biochem. 72: 1299-1306.

15. Nomura M, Nakajima I, Fujita Y, Kobayashi M, Kimoto H, Suzuki I, et al. 1999. Lactococcus lactis contains only one glutamate decarboxylase gene. Microbiology 145: 1375-1380.

16. Nomura M, Kimoto H, Someya Y, Furukawa S, Suzuki I. 1998. Production of $\gamma$-aminobutyric acid by cheese starters during cheese ripening. J. Dairy Sci. 81: 1486-1491.

17. Fan E, Huang J, Hu S, Mei L, Yu K. 2012. Cloning, sequencing and expression of a glutamate decarboxylase gene from the GABAproducing strain Lactobacillus brevis CGMCC1306. Ann. Microbiol. 62: 689-698.

18. Fonda ML. 1985. L-Glutamate decarboxylase from bacteria. Methods Enzymol. 113:11-16.

19. Lin Q, Yang S, Lu F, Lu Z, Bie X, Jiao Y, et al. 2009. Cloning and expression of glutamate decarboxylase gene from Streptococcus thermophiles Y2. J. Gen. Appl. Microbiol. 55: 305-310.

20. Nomura M, Kobayashi M, Ohmomo S, Okamoto T. 2000. Inactivation of the glutamate decarboxylase gene in Lactococcus lactis subsp. cremoris. Appl. Environ. Microbiol. 66: 2235-2237.

21. Seo MJ, Nam YD, Lee SY, Park SL, Yi SH, Lim SI. 2013. Expression and characterization of a glutamate decarboxylase from Lactobacillus brevis $877 \mathrm{G}$ producing $\gamma$-aminobutyric acid. Biosci. Biotechnol. Biochem. 77: 853-856.

22. Kim H-W, Kashima Y, Ishikawa K, Yamano N. 2009. Purification and characterization of the first archaeal glutamate decarboxylase from Pyrococcus horikoshii. Biosci. Biotechnol. Biochem. 73: 224-227.

23. Tsuchiya K, Nishimura K, Iwahara M. 2003. Purification and characterization of glutamate decarboxylase from Aspergillus oryzae. Food Sci. Technol. Res. 9: 283-287. 
24. Yu J-J, Oh S-H. 2011. $\gamma$-Aminobutyric acid production and glutamate decarboxylase activity of Lactobacillus sakei OPK2-59 isolated from Kimchi. Korean J. Microbiol. 47: 316-322.

25. Komatsuzaki N, Nakamura T, Kimura T, Shima J. 2008. Characteri- zation of glutamate decarboxylase from a high $\gamma$-aminobutyric acid (GABA)-producer, Lactobacillus paracasei. Biosci. Biotechnol. Biochem. 72: 278-285. 